\title{
PENYULUHAN PERENCANAAN USAHA MIKRO, KECIL, DAN MENENGAH (UMKM) DI LINGKUNGAN RT002/02, KEBAYORAN LAMA UTARA, KEBAYORAN LAMA, JAKARTA SELATAN
}

\author{
Guston Sitorus *) \\ *)Dosen Tetap Program S1 Jurusan Manajemen Fakultas Ekonomi Universitas Satya Negara Indonesia
}

Email: mkb guston01@yahoo.com

\begin{abstract}
Analisis Situasi
Usaha Mikro, Kecil dan menengah di Indonesia atau disingkat dengan UMKM merupakan salah satu nafas ekonomi masyarakat Indonesia, karena sektor UMKM ini paling menyedot tenaga kerja dan paling banyak digeluti masyarakat Indonesia. Usaha Mikro, Kecil dan Menengah (UMKM) mempunyai peran penting dan strategis dalam pembangunan ekonomi nasional. Selain berperan dalam pertumbuhan ekonomi dan penyerapan tenagakerja, UMKM juga berperan dalam mendistribusikan hasil-hasil pembangunan. UMKM juga telah terbukti tidak terpengaruh terhadap krisis. Ketika krisis menerpa pada periode tahun 1997 1998, hanya UMKM yang mampu tetap berdiri kokoh.
\end{abstract}

Hampir di seluruh Indonesia UMKM merupakan kegiatan ekonomi yang paling menonjol dan paling banyak jenis kegiatannya termasuk kegiatan di pasar-pasar tradisional maupun kegiatan bisnis rumahan. Hal yang sama masyarakat di Kota Jakarta juga menekuni berbagai bisnis UMKM, terutama pedagang kecil, pedagang kaki lima, ataupun binis rumahan, yang masih tergolong dengan tradisional.

UMKM di Kota Jakarta memiliki berbagai kekuatan dan kelemahan dalam menghadapi persaingan yang semakin ketat. Menurut Suryana (2001: 85- 86) usaha kecil memiliki kekuatan dan kelemahan tersendiri. Beberapa kekuatan UMKM antara lain, Pertama, memiliki kebebasan untuk bertindak, artinya bila ada perubahan misalnya perubahan produk baru, teknologi baru, dan perubahan mesin baru, UMKM bisa bertindak dengan cepat untuk menyesuaikan dengan keadaan yang berubah tersebut. Kedua, feleksibel, UMKM dapat menyesuaikan dengan kebutuhan setempat, bahan baku, tenaga kerja, dan pemasaran produk usaha kecil pada umumnya menggunakan sumber - sumber setempat yang bersifat lokal. Sedangkan yang Ketiga, tidak mudah goncang, karena bahan baku kebanyakan lokal dan sumber daya lainnya bersifat lokal, maka perusahaan kecil tidak rentan terhadap fluktuasi bahan baku impor.

Sedangkan yang menjadi kelemahan UMKM dapat dikelompokkan ke dalam dua aspek, yaitu Pertama aspek kelemahan struktural, yaitu kelelemahan dalam strukturnya, misalnya kelemahan dalam bidang manajemen dan organisasi kelemahan dalam pengendalian mutu, kelemahan dalam mengadopsi dan penguasaan teknologi, kesulitan mencari permodalan, tenaga kerja masih lokal, dan terbatasnya akses pasar. Kedua, kelemahan kultural, mengakibatkan kelemahan struktural, kurangnya akses informasi dan lemahnya berbagai persyaratan lain guna memperoleh akses permodalan, pemasaran, dan bahan baku seperti informasi peluang dan cara memasarkan produk, informasi untuk mendapatkan bahan baku murah dan mudah didapat informasi untuk memperoleh fasilitas dan bantuan pengusaha besar dalam menjalin hubungan kemitraan untuk memperoleh bantuan permodalan dan 
pemasaran informasi tentang tata cara pengembangan produk baik desain, kualitas maupun kemasannya, serta informasi untuk menambah sumber permodalan dengan persyaratan yang terjangkau.

Selain berbagai kelemahan UMKM di atas terdapat juga kendala yang berasal dari faktor internal dan eksternal. Kendala yang dihadapi UMKM dari faktor internal adalah masalah manajemen, pemasaran, modal, sumber daya manausia, hukum, akuntabilitas dan sebagainya Sementara itu kendala yang dihadapi UMKM yang merupakan factor eksternal adalah iklim usaha, infrastruktur, akses, dan sebagainya. Dilihat dari kendala-kendala yang ada masalah yang dihadapi UMKM salah atunya terkait dengan kemampuan para pedagang kecil dalam menyusun renana usahanya. Kemampuan pemahaman tentang perencanaan UMKM yang rendah ini mengakibatkan perkembangan usaha kecil ini sangat lambat. Perencanaan Binsis atau UMKM ini belum berjalan dengan baik pada dasarnya para pedagang kecil di lingkungan RT002/02 Kebayoran Lama Utara, Kebayoran Lama, Jakarta Selatan belum memiliki wawasan yang bagus tentang perencanaan bisnisnya untuk itu perlu dilakukan pelatihan atau penyuluhan tentang perencanaan bisnis atau perencanaan UMKM.

Penyuluhan Perencanaan UMKM akan memberikan manfaat yang sangat besar bagi para pedagang kecil di lingkungan RT002/02 Kebayoran Lama Utara, Kebayoran Lama, Jakarta Selatan yang meliputi, Penyusunan Rencana, Manfaat Perencanaan, Perencanaan Produk, Perenanaan Harga, Perencanaan Keuangan, dan Perencanaan Pemasaran.

Dari berbagai penjelasan di atas maka sanngat diperlukan penyuluhan bagi para pedagang kecil di lingkungan Rt004/02 Kebayoran Lama Utara, Kebayoran Lama, Jakarta Selatan untuk meningkatkan kemampuan pedagang kecil untuk memasarkan usahanya.

Penyuluhan Perencanaan UMKM ini akan dilakukan oleh Dosen Tetap dan mahasiswa Program Studi Manajemen Fakultas Ekonomi USNI dengan Judul "Penyuluhan Perencanaan Usaha Mikro, Kecil, dan Menengah (UMKM) di Lingkungan RT002/02, Kebayoran Lama Utara, Kebayoran Lama, Jakarta Selatan".

Adapun permasalahan yang dihadapi para pedagang kecil di lingkungan RT002/02 Kebayoran Lama Utara, Kebayoran Lama, Jakarta Selatan, yaitu Mitra UMKM belum mampu menyusun perencanaan bisnis sehingga belum mampu merencakan kegiatannya secara matang dari waktu ke waktu, Mitra UMKM belum mampu menyusun Perencanaan Produk sehingga belum mampu menyediakan produk yang sesuai dengan kebutuhan konsumennya, Mitra UMKM belum mampu menyusun Perenanaan Harga, sehingga belum mampu menetapkan harga bersaing, Mitra UMKM belum mampu menyusun Perencanaan Lokasi, sehingga belum mampu menentukan kapan dan dimana produknya dijual agar mudah diperoleh langgananya, dan Mitra UMKM belum mampu menyusun Perencanaan Promosi, sehingga belum mampu memberitahukan kepada pelanggannya tentang pemasaran usahanya..

\section{Solusi Permasalahan}

Untuk menyelesaikan berbagai masalah yang dihadapi para pedagang kecil di lingkungan RT002/02 Kebayoran Lama Utara, Kebayoran Lama, Jakarta Selatan maka perlu dilakukan penyuluhan. Adapun materi penyuluhan yang akan diberikan kepada para pedagang kecil tersebut adalah yang berhubungan dengan Perencanaan UMKM. 
Perencanaan merupakan hal pokok dan sangat penting untuk melakukan suatu praktek manajemen. Pentingnya perencanaan bukan hanya pada organisasi kecil melainkan juga dalam tingkatan perusahaan besar dan bahkan perusahaan multi nasional (Multi National Company). Perencanaan adalah proses menetapkan sasaran dan menilai cara sasaran-sasaran ini dapat dicapai dengan cara yang paling baik.Jika dilihat dari pengertian atau definisi diatas maka perencanaan mengandung 2 (dua) arti didalamnya, yaitu adanya tujuan (apa yang harus dikerjakan) dan sasaran-sasaran (bagaimana harus dilakukan).

Manfaat yang dapat diperoleh dari penyusunan perencanaan bisnis yaitu agar dapat mengidentifikasi pihak-pihak yang akan membacanya, yaitu investor, perbankan, pelanggan, konsultan, pemerintah, dan pihak lain yang terkait. Perencanaan bisnis harus disusun sedemikian rupa sehingga dapat memberikan manfaat, terutama dalam mewujudkan gagasan merintis berdirinya perusahaan.

Perencanaan produk juga tidak kalah pentingnnya untuk menjami kuantitas dan kualitas yang ditawarkan kepada konsumen. Perencanaan produk ini dimulai dari pengadaan bahan (menyangkut jenis, volume, harga sumber (daerah) pasokan bahan, proses pengadaan bahan, serta proyeksi peningkatanya dalam setiap periode/siklus produksi). Kemudian menentukan kebutuhan sumber daya produksi (uraian mengenai sumber daya produksi meliputi bangunan, peralatan/mesin, dan tenaga kerja yang dibutuhkan untuk melaksanakan aktivitas produksi, berkaitan dalam jumlah, kualitas, nilai, serta proses pengadaanya). Menentukan proses produksi (proses produksi masing-masing jenis produk yang disertai dengan bagan proses produksi), termasuk perkiraan jumlah produksi dan proyeksi peningkatanya dalam setiap periode/siklus. Terakhir menentukan anggaran produksi (uraian berdasarkan rencana biaya produksi yang dialokasikan untuk investasi dan baiaya untuk operasional produksi dalam satu siklus dan proyeksi peningkatanya sejalan dengan peningkatan produksi untuk memenuhi peningkatan permintaan pasar).

Harga jual suatu produk dapat direncanakan dengan baik dengan cara terlebih dahulu menentukan tujuan penetapan harga tersebut sehingga menjadi pedoman dalam menetapkan harga jualdimaksud. Terdapat beberapa tujuan penetapan harga jual, ysaitu berorientasi pada aba, bahwa setiap perusahaan selalu memilih harga yang dapat menghasilkan laba, berorientasi pada volume, bahwa penetapan harga sedemikian rupa agar dapat mencapai tingkat volume penjualan tertentu, berorientasi pada citra (image), bahwa penetapan harga tertentu dapat membentuk citra perusahaan, dan berorientasi pada Stabilitas Harga, hal ini dilakukan untuk mempertahankan hubungan yang stabil antara suatu perusahaan dengan harga pemimpin industri (industry leader).

Perencanaan lokasi bisnis yang tepat diharapkan dapat memenuhi harapan pengusaha untuk menarik konsumen dalam rangka mendapatkan keuntungan. Maka, pemilihan lokasi bisnis yang dekat dengan target pasar serta ketersediaan infrastruktur yang memadai merupakan sebuah strategi yang juga dapat memudahkan konsumen untuk mendapatkan produk/jasa yang diinginkannya. Beberapa faktor yang mempengaruhi pemilihan lokasi bisnis yaitu lingkungan masyarakat, sumber daya alam, tenaga kerja, kedekatan dengan pasar, fasilitas dan biaya transportasi, tanah untuk ekspansi, dan pembangkit tenaga listrik.

Perencanaan promosi merupakan salah satu hal yang terpenting dalam memasarkan usaha, meliputi periklanan, personal selling, sales promotion, publisitas, direct selling atau 
direst marketing. Promosi yang lazim dilakukan oleh para pengusaha yaitu berupa iklan. Iklan pun dapat dibagi menjadi dua fungsi yaitu sebagai pemberi informasi dan juga ada yang bersifat membujuk

\section{Luaran Penyuluhan}

Sesuai dengan beberapa solusi untuk menyelesaikan berbagai masalah yang dihadapi para pedagang kecil atau mitra UMKM, maka akan dilaksanakan penyuluhan dengan harapan akan dapat meningkatkan kemampuan para pedagang kecil berupa luaran penyuluhan, yaitu Mitra UMKM akan mampu menyusun perencanaan bisnis sehingga mampu merencakan kegiatannya secara matang dari waktu ke waktu, Mitra UMKM akan mampu menyusun Perencanaan Produk sehingga mampu meyediakan produk yang sesuai dengan kebutuhan masyarakat, Mitra UMKM akan mampu menyusun Perenanaan Harga, sehingga mampu menetapkan harga bersaing, Mitra UMKM akan mampu menyusun Perencanaan Lokasi, sehingga mampu menentukan kapan dan dimana produknya dijual agar mudah diperoleh langgananya, dan Mitra UMKM akan mampu menyusun Perencanaan Promosi, sehingga mampu memberitahukan kepada pelanggannya tentang pemasaran usahanya.

\section{Metodologi Penyuluhan}

Penyuluhan ini akan dilakukan dengan metode ceramah dimana peserta akan diberikan penjelasan baik secara teori dan ilustrasi yang relevan dengan topik. Beberapa bahan dan alat penyuluhan yang dibutuhkan, antara lain persiapan ruangan, spanduk, kuesioner, toa, materi pelatihan (power point), lap top, dan proyektor (infokus).

Data yang dikumpulkan dalam penyuluhan ini adalah data primer, yaitu data yang diperoleh dari jawaban para peserta penyuluhan, yang diperoleh melalui kuesioner yang diisi peserta sebelum dan sesudah penyuluhan.

Data yang sudah dikumpulkan dianalisis dengan menggunakan statistic, yaitu mendiskripsikan data-data masing-masing variabel secara partial. Statistik deskriptif yang digunakan adalah rata-rata, modus nilai yang sering muncul), median (nilai tengah), standar deviasi, variansi, frekuensi, dan histogram.

Hipotesis yang digunakan dalam pengabdian kepada masyarakat ini adalah Ho : Tidak ada perbedaan kemampauan pedagang kecil sebelum dan sesudah penyuluhan dan Ha : Ada perbedaan kemampauan pedagang kecil sebelum dan sesudah penyuluhan. Untuk membuktikan hipatesisi ini digunakan Uji Beda (T Test) atau Uji Perbandingan Dua Rata-rata (Paired Samples Test), yaitu menganalisis perbedaan kemampuan peserta sebelum dan sesudah penyuluhan, yang meliputi Paired Samples Statistics, Paired Samples Correlations, dan Paired Samples Test.

\section{Keberhasilan Penyuluhan Perencanaan UMKM}

\section{a. Keberhasilan Penyuluhan Perencanaan Bisnis}

Dari data atau jawaban peserta yang sudah diolah dapat dijelaskan bahwa sebelum mengikuti penyuluhan $80 \%$ peserta kurang atau belum mampu merencanakan bisnisnya dan sesudah mengikuti pelatihan 56,7\% peserta mampu memahami perencanaan bisnisnya. 
Artinya Penyuluhan Perencanaan Bisnis ini berhasil meningkatkan kemampuan pedagang kecil dalam memahami perencanaan bisnisnya.

\section{b. Keberhasilan Penyuluhan Perencanaan Produk}

Dari data atau jawaban peserta yang sudah diolah dapat dijelaskan bahwa sebelum mengikuti penyuluhan 53\% peserta kurang mampu memahami perencanaan produknya dan sesudah mengikuti pelatihan $60 \%$ peserta mampu memahami perencanaan produknya. Artinya Penyuluhan Perencanaan Produk ini berhasil meningkatkan kemampuan pedagang kecil dalam memahami perencanaan produknya.

\section{c. Keberhasilan Penyuluhan Perencanaan Harga}

Dari data atau jawaban peserta yang sudah diolah dapat dijelaskan bahwa sebelum mengikuti penyuluhan $60 \%$ peserta belum mampu memahami perencanaan harga produknya dan sesudah mengikuti penyuluhan $56,7 \%$ peserta mampu memahami perencanaan harga produknya. Artinya Penyuluhan Perencanaan Harga ini berhasil meningkatkan kemampuan pedagang kecil dalam memahami perencanaan harga produknya.

\section{d. Keberhasilan Penyuluhan Perencanaan Lokasi}

Dari data atau jawaban peserta yang sudah diolah dapat dijelaskan bahwa sebelum mengikuti penyuluhan $80 \%$ peserta belum mampu memahami perencanaan lokasi usahanya dan sesudah mengikuti penyuluhan $60 \%$ peserta sudah mampu memahami perencanaan lokasi usahanya. Artinya Penyuluhan Perencanaan Lokasi ini berhasil meningkatkan kemampuan pedagang kecil dalam merencanakan lokasi usahanya.

\section{e. Keberhasilan Penyuluhan Perencanaan Promosi}

Dari data atau jawaban peserta yang sudah diolah dapat dijelaskan bahwa sebelum mengikuti penyuluhan $60 \%$ peserta belum mampu memahami perencanaan promosinya dan sesudah mengikuti pelatihan $70 \%$ peserta sudah mampu memahami perencanaan promosinya. Artinya Penyuluhan Perencanaan Promosi ini berhasil meningkatkan kemampuan pedagang kecil dalam memahami perencanaan promosinya.

\section{Peningkatan Kemampuan Peserta Sesudah Penyuluhan}

Dari hasil pengeolahan data dapat dilihat bahwa kemampuan pedagang kecil di RT002/02 Kebayoran Lama Utara, Kebayoran Lama, Jakarta Selatan, sesudah mengikuti penyuluhan Perencanaan UMKM meningkat secara signifikan, yaitu kemampuan sangat memahamii (A) naik sebesar $+18,68 \%$, memahami (B) naik sebesar $+56.08 \%$, sedangkan cukup memahami (C) turun $-19,00 \%$, kurang memahami (D) turun $-66,70 \%$, dan sangat kurang memahami (E) turun $-22,1 \%$. Artinya pelaksanaan penyuluhan Perencanaan UMKM BERHASIL meningkatkan pemahaman dan kemampuan pedagang kecil di wilayah RT002/02 Kebayoran Lama Utara, Kebayoran Lama, Jakarta Selatan untuk merencanakan usahanya.

\section{Uji Perbandingan Dua Rata-Rata (Paired Samples Test) a. Paired Samples Statistics}

Dari hasil pengeolahan data dapat dijelaskan tentang statistik data dari sampel berpasang-pasangan, yaitu kemampuan rata-rata sebelum mengikuti penyuluhan adalah 
sebesar 20.000, sedangkan sesudah penyuluhan rata-rata kemampuan 38.8000 , artinya terjadi peningkatan kemampuan peserta sebesar 18,8.

\section{b. Paired Samples Test}

Dari hasil pengeolahan data dapat dijelaskan tentang hasil uji sampel berpasangan (Paired samples T Test), diketahui nilai signifikansi (Sig 2-tailed) sebesar 0,000 nilainya kurang dari 0,05, maka kesimpulannya Ho Ditolak dan Ha Disterima, artinya terdapat perbedaan kemampuan peserta sebelum dan sesudah penyuluhan. Jadi dapat disimpulkan terdapat perbedaan kemampuan peserta sebelum dan sesudah penyuluhan.

\section{Kesimpulan}

Kemampuan pengusaha kecil dan menengah dalam mengelola usahanya sebelum mengikuti penyuluhan dapat dikatakan berada pada tingkat kurang memahami, dan sesudah mengikuti penyuluhan dapat dikatakan berada pada tingkat memahami.

Terdapat perbedaan kemampuan rata-rata peserta penyuluhan sebelum dan seusah penyuluhan. Sebelum mengikuti penyuluhan adalah rata-rata kemampuan rata-rata sebelum mengikuti penyuluhan adalah sebesar 20.000, sedangkan sesudah penyuluhan rata-rata kemampuan 38.8000, artinya terjadi peningkatan kemampuan peserta sebesar 18,8.

Pelaksanaan P2M dengan topik "Penyuluhan Pemasaran UMKM di RT002/02 Kebayoran Lama Utara, Kebayoran Lama, Jakarta Selatan" dapat dikatakan Berhasil meningkatkan kemampuan pedagang kecil dalam memehami perencanaan usahanya.

\section{Saran}

Penyuluhan seperti ini sebaiknya dapat dilakukan secara berkesinambungan dengan tingkat pelaksanaan yang lebih berkualitas dan daerah jangkauan penyuluhan yang semakin luas, dan juga dapat melibatkan lebih banyak dosen dengan berbagai aspek ilmu dan pengetahuan yang dimilkinya, serta meningkatkan biaya pelaksanaan $\mathrm{PkM}$, sehingga kulitas dan kuantitas pelaksanaan dapat ditingkatkan.

\section{DAFTAR PUSTAKA}

Boone, Louis E. and David L. Kurtz, 2005, Contemporary Marketing 2005, Thomson South Western, Ohio, USA

Brotodiharjo Santoso, Pengantar Ilmu Pajak, Bandung: Eresco NU, 2008.

Brenda Kienan, "Small Business Solution E-commerce", Penerbit Gramedia, Jakarta, 2001.

Geoffrey G. Meredith, Kewirausahaan Teori dan Praktek, Jakarta: PT. Pustaka Binaman Pressindo, 2010.

Gendut Sukarno (2009) Meningkatkan kinerja pemasaran UMKM, Jurnal Equitas Vol 15 No UPN Surabaya tanggal 3 September 2011.

Hurriyati, Ratih. Bauran Pemasaran dan Loyalitas Konsumen. Cetakan Pertama, Bandung, Penerbit ALFABETA, 2005.

Kotler Philip dan Gary Armstrong, Dasar-dasar Pemasaran, Jilid I, Edisi ke 10, Jakarta: Indeks, 2010.

Kotler Philip dan Kevin Lane Keller, Manajermen Pemasaran, Jili I, Edisi 12, Jakarta: Indeks. 2009.

Lupiyod, Rambat. Pengertian Produk. Jakarta, Penerbit : Sandi Susono, 2001. 
Prawirosentono, Suryadi. Total Quality Manajemen ABAD 21, Edisi Revisi, Penerbit PT. Bumi Aksara, 2004.

Rangkuti Freddy, Measuring Customer Satisfaction: Gaining Customer Relationship Strategy (Teknik Mengukur dan Strategi Meningkatkan Kepuasan Pelanggan), Jakarta, Salemba Empat 2008.

Reedy, J., Schullo, S., \& Zimmerman, K. (2000). Electronic marketing, integrating electronic resources into the marketing process. United States of America: The Dryden Press, Harcourt College Publishers.

Robbins Stephen P. dan Mary Coulter, Manajemen, Edisi Kesepuluh, Jakarta: Airlangga 2011.

Winarti, Safitri Endah, 2011. Kebijakan Pemerintah Kota Yogyakarta dalam Dalam Penanganan Pelaku Ekonomi Kerakyatan (Hasil Penelitian). 